\title{
Impact and Benefit Agreement (IBA) Revenue Allocation Strategies for Indigenous Community Development
}

\author{
Thierry Rodon \\ Université Laval \\ Isabel Lemus-Lauzon \\ IDDPNQL", Québec
}

Stephan Schott

Carleton University

\begin{abstract}
This article analyzes the different modes of resource revenue allocation and their impacts on Indigenous communities and sustainable development. After a literature review of the different distribution and investment models and their positive and negative impacts for communities, we assess each model's level of sustainability. In the second section, we present the results of a survey and follow-up interviews conducted with twenty-one representatives of the fortytwo Canadian First Nations that had signed an Impact and Benefit Agreement by 2016. In most surveyed communities, the trust funds are directly managed by the political authority thus providing no insulation from political influence. The survey also shows that some Indigenous communities are investing in programs that should be funded by the federal and provincial or territorial governments, which attests to the chronic lack of investment in Indigenous communities in Canada. Finally, whatever the choice of distribution or investment strategy, in order to foster sustainable development communities need to ensure that the lost natural capital-both non-renewable resources depletion and the environmental damage created by the operations-will be replaced for future generations.
\end{abstract}

"I'Institut de développement durable des Premières Nations du Québec et du Labrador (Institute for Sustainable Development of First Nations of Quebec and Labrador)

The Northern Review 47 (2018): 9-29

Published by Yukon College, Whitehorse, Canada 


\section{Introduction}

In Canada, Indigenous people are increasingly able to obtain a share of the revenue from resource development that takes place in their territory. The different court cases have made it clear that Indigenous peoples need to be consulted and that in some case their consent might be necessary (Papillon and Rodon 2017). The development of non-renewable resources in northern Canada has led many mining, oil extraction, and hydroelectric companies to negotiate resource revenue sharing agreements through Impact and Benefit Agreements (IBA) or similar agreements with Indigenous communities (Prno et al. 2010). The negotiation of these agreements greatly reduces uncertainties over the legality and the legitimacy of a given project, considering the legal context surrounding resource development and Indigenous land rights in Canada (Papillon and Rodon 2017, Bradshaw and McElroy 2014). These agreements are also seen by many project proponents as a way to facilitate the acceptability of development projects on Indigenous lands since they establish guidelines for Indigenous employment, community development, and often include provisions for profit sharing.

Resource revenue can be shared in many ways. Sharing arrangements can include profits, the value of production, or production rates. There can also be fixed payments that will allow communities to cover their IBA administration expenses (Gibson and O'Faircheallaigh 2010). The sums of money coming from profit sharing and revenues are generally paid to the organization and/or community that has signed the agreement with the company. In turn, this organization or community is responsible for distributing the sums paid by the company. There are no uniform ways to distribute these sums. For example, in some cases, revenue may be distributed directly to individuals. In others, it may be used for community projects or invested in resource trust funds.

In fact, there are only a few studies regarding the local community impacts of the different modes of allocating revenues and profit shares (Altman and Levitus 1999; NWT 1989; O'Faircheallaigh 2010, 2012). What are the social and economic impacts of the various modes of distribution and investment? Are there modes that can better mitigate the impacts of a non-renewable development on Indigenous communities? Are some modes of distribution or investment better/worse at enabling communities to benefit from this wealth? Which models provide the most intragenerational and intergenerational equity and sustainability? This is a challenging task 
balancing the needs of households and communities today with the needs and lost opportunities of future generations.

The research reported in this article aimed at bridging the knowledge gap regarding modes of revenue allocation and their impacts. More specifically, the objectives were to 1) categorize the various methods used by Indigenous communities and organizations to distribute revenues and profit shares paid by resource companies; 2) identify the characteristics of each mode of distribution and investment and its positive and negative outcomes; and 3) assess the contribution of different modes to the sustainability of Indigenous communities. Moreover, we hope that this research will help communities to make more informed and enlightened decisions when deciding on a distribution or investment strategy.

This article is divided into three sections. First, we will present a literature review of the different models for distributing resource revenues and their positive and negative impacts for communities. We will also assess their level of sustainability. In the second section, we present the results of a survey and follow-up interviews conducted with representatives from twenty-one Canadian First Nations that have signed a profit-sharing agreement. We conclude with a discussion of the survey results.

\section{Characteristics of Resource Revenue Allocation}

Non-renewable resources are a depletable asset. Any exploitation diminishes availability of the resource to future generations unless the returns or rents ${ }^{1}$ from its extraction are reinvested in other assets that benefit future generations. Sustainability principles, therefore, should be based on the Hartwick rule (Hartwick 1977, 1978), which states that at every point in time the total rent arising in the resource extraction industry must be saved and invested in reproducible capital. This will at least guarantee continuing consumption levels for future generations that benefit from the returns of the transformed levels of capital. For this reason, some economists (Markus Herrman in Northern Sustainable Development Research Chair 2013, 14-15) advise that resource revenue should be invested in trust funds, and that only the interest generated should be spent. This would ensure that the capital is not "spent" and can benefit future generations.

In this section, drawing on the existing literature, we will discuss the different resource revenue allocation models and their negative and positive outcomes for Indigenous communities. The review presented here is not exhaustive but examines the four more widely used models: Direct 
payments, trust funds, social programs and services, and infrastructure investments.

Direct Payments to Individuals

The Direct Distribution Model (DDM) transfers resource revenues directly to individuals. Different operational definitions exist such as lump sum payments, conditional cash transfers, and dividends (see Segal 2012b for an in-depth discussion of DDM). This system is likely the simplest allocation model and presents the potential to reduce social and revenue inequalities, poverty-especially extreme poverty-and could provide greater social and income security to the most vulnerable (Gupta et al. 2014; Standing 2008; Standing 2014; DFID 2011; Segal 2011, 2012b; Gibson and O'Faircheallaigh 2010; O'Faircheallaigh 2010, 2012; Moss 2010; Soares et al. 2007; Cornell et al. 2007; Schubert and Huijbregts 2006; Morley and Coady 2003; Bunting and Truelove 1970). Moreover, the DDM provides beneficiaries with the freedom to decide how to spend the money, may it be for urgent needs or long-term investments (O'Faircheallaigh 2010, 2012; Moss 2010; Gibson and O'Faircheallaigh 2010; Cornell et al. 2007; Weinthal and Jones Luong 2006; Palley 2003). For some citizens who live off-reservation or outside the region, this model allows them to benefit from the nation's success (Cornell et al. 2007). Regarding governance and democracy, direct payments could certainly contribute to reducing corruption and rent-seeking behaviour, leading to a more responsible and transparent governance of the funds (Gupta, Segura-Ubiergobas, and Flores 2014; Segal 2012b, 345; Moss 2010; Cornell et al. 2007; Weinthal and Jones Luong 2006; Palley 2003). Additionally, this model could have a positive impact on political participation and stronger institutions since it would increase the interest of citizens in the management of the resource revenues due to their personal stake in the profit (Gupta et al. 2014; Standing 2014; Devarajan et al. 2011; Gillies 2010; Moss 2010; Weinthal and Jones Luong 2006; Mahon 2005; Birdsall and Subramanian 2004; Palley 2003; Sala-i-Martin and Subramanian 2003).

If direct payments offer many benefits, they are also likely to provoke tension among the population between beneficiaries and non-beneficiaries (O'Faircheallaigh 2013; Gibson and O'Faircheallaigh 2010), besides fostering disputes over the borders of tribal territories (O'Faircheallaigh 2016) and Indigenous citizenship (Cornell et al. 2007). Moreover, direct payments are associated with a disincentive to work and with destructive behaviours such as substance abuse and domestic violence (Hill 2012; Cornell et al. 2007; Bunting and Truelove 1970). In 
addition, this distribution system assumes individuals will to some extent invest revenues in the form of savings or investments for their children or grandchildren. Given the limited incomes of Indigenous households and the generally low saving rates among them (O'Faircheallaigh 2010, 2012), this type of redistribution will not guarantee that even weak principles of sustainability will be adhered to.

\section{Trust Funds}

Trust funds are another popular means to manage natural resource revenues. Their definitions and legal structures greatly vary. For example, stabilization funds essentially reduce potential impacts due to the volatility and help stabilize the pace of government spending, while trusts are savings funds that transfer a portion of the revenues to future generations (Baena et al. 2012). A common characteristic is that trust funds are (in theory) managed by a distinctive agency and are separated from the fiscal budget (Baena et al. 2012; World Bank 2011).

It is quite clear from the literature that trust funds can represent an opportunity to accumulate an asset base from mining payments. In comparison to direct payments, this strategy has the potential to generate stable, long-term, and sustainable revenue for the future, thus promoting intergenerational equity (Soderholm and Svahn 2015; Tsani 2013; Baena et al. 2012; O'Faircheallaigh 2010, 2012; Gibson and O'Faircheallaigh 2010; Fischer 2007; Poole et al. 1992).

Critics argue that the actual resource revenue invested in trust funds is unavailable to address other needs or current operations of the community, and neither are they available for direct distribution (O'Faircheallaigh 2010, 2012; Gibson and O'Faircheallaigh 2010; Cornell et al. 2007). Thus, for countries rapidly growing, and those with significant poverty, in the short term, saving less and spending more in the present time could be a better strategy for current, and to some extent even future, generations (Segal 2012a).

\section{Social Programs and Public Services}

Mining projects often exist in areas where government capacity may be weak or regional government may simply be absent. When public services are inadequate, governments may promote the spending of resource revenue to fill gaps in public service or to extend the scope of services being provided. For instance, the investments might be made in cultural programs, education, and health care. On the positive side, this strategy allows Indigenous peoples to have a greater control over the priorities 
and decisions about these services (O'Faircheallaigh 2004). Such a use of funds may also offer them opportunities to develop and improve their administrative skills and their capacity for self-governance (Cornell 2006; O'Faircheallaigh 2004). The latter could benefit future generations by making them more autonomous and in control of their own economic, social, and cultural direction. By choosing to invest in public services, the community could experience greater social returns because the overall return on investment is greater than just financial (Segal 2012b, 343; Collier et al. 2009, 98-99).

However, the investment of mining revenue in essential public services (health, education) or community programs can result in the disengagement of the central government that should be the agency responsible for providing these services in the first place, and risks establishing a dependency of the institutions towards development (Gibson and O'Faircheallaigh 2010; O'Faircheallaigh 2004, 2010, 2012).

\section{Infrastructure Investments}

Investments are also made in community infrastructure. The advantage of community infrastructure is that it can benefit the community at large. Moreover, assets are available for longer time periods if properly maintained. The downside is that infrastructure needs to be maintained and requires services. It is important that the upkeep is built into the finance model, perhaps by continuous support of the extractive industry during the lifecycle of their operations. It then could have spinoff effects, as new economic operations and jobs might be created through the infrastructure construction and operation.

The four revenue distribution and investment models presented above-direct payments (short-term private handouts); trust funds (longterm investments); investments in social programs and public services; and infrastructure (short-, mid- and long-term public investments) - all present benefits and drawbacks for Indigenous communities.

\section{Assessing the Revenue Allocation Strategies According to Sustainability Criteria}

In order to go further in assessing the merit of each strategy we use specific sustainability criteria. Gibson (2006) has developed an ambitious framework to assess sustainability in the context of resource development, but in the case of resource revenue allocation the main criteria are intragenerational and intergenerational equity. Intragenerational equity measures the equity of revenue distribution or investment in the region, 
community, and among different groups; intergenerational refers to the equity between different generations. Some authors have insisted on the interconnection of both forms of equity (Weiss 1992; Godden 2009), but others (Dobson 1999; Gosseries 2008) argue that these two kinds of equity are often in conflict. Since mines are depletable assets, intergenerational equity is a crucial issue in this sector-although the lack of intragenerational equity can be a major source of social conflict within Indigenous communities, making it difficult or impossible to address issues of intergenerational equity. Finally, as we will see later, the lack of intergenerational equity is clearly a major issue for some of this study's respondents.

Direct payments to individuals score low on intragenerational equity but can be high on intergenerational equity since the cash is usually distributed equally amongst community members (although some communities located further from the development are usually not included). Furthermore, if cash transfers can address urgent needs, they cannot secure lasting benefits. Thus, this model fails to address other causes of poverty, such as access to education and civil rights, and is not sufficient to ensure economic well-being in the long run, therefore lacking intergenerational equity (Gupta et al. 2014; Cornell et al. 2007; Bunting and Truelove 1970; Hartwick 1977, 1978).

Programs and services: Regarding investments in public services and community programs, the volatility and unpredictability of mineral markets make them vulnerable to the mining "boom and bust" cycles. One can argue that funds should preferably address the negative outcomes of mining and create opportunities for improving the economic situation. They therefore could act as automatic stabilizers that invest into programs, services, and spinoff activities in boom periods, and that later can make up for some of the downturns in bust periods. Programs and services can address issues of intragenerational equity through policies designed to support neglected or undersupplied areas (e.g., through income support, advancement of health services, and additional retirement support to name a few).

Investment in infrastructure seems like a good way to use resource revenue, although it is highly dependent on the type of infrastructure that is built. In general, Indigenous communities use the money for collective infrastructure such as a gathering place, but also arenas or swimming pools, and in rare cases to build social housing. These investments contribute to improving well-being and social cohesion, two elements that are often threatened by resource development. However, in the case 
of infrastructure that needs constant investment in order to function, like swimming pools, their usefulness often doesn't go beyond the resource development lifetime. As for services, it also allows governments to avoid investing, especially in the case of social housing. The latter can create a false sense of security for the community and regions, and can result in loss of support or transfer payments from central governments. This type of investment can contribute both to intra- and intergenerational equity, but only if the infrastructures are well-designed and maintained, which is often not the case.

Trust funds are in essence geared towards intragenerational equity since usually the capital is invested and only the interest is spent. However, investments, especially in the marketplace, can be risky; during the last financial crisis many community trust funds lost an important part of their value. Trust funds, therefore, have to be treated as long-term investments, which implies that some years there might not be returns and they cannot always be relied on for constant streams of revenues. The governance of the trust funds is also a key element. In most Indigenous communities that were surveyed, the trust funds were administered by the political authority, which makes these funds susceptible to political motivation, and therefore risky investments. It is also difficult to convince community authorities to establish such a fund since their community is often in great need of investments and infrastructure and programs to relieve poverty. A future vision for how these funds will contribute to future investments and expenditures is essential in persuading the public and community authorities.

Table 1 summarizes the advantages and disadvantages of each allocation mode and assesses their relative sustainability. In many cases, Indigenous communities use a mix of distribution or investment strategies, which allows them to address urgent needs such as poverty relief, housing, and food security but allows them to keep some funds for medium- and long-term needs. Many Indigenous communities face both urgent immediate needs and long-term objectives such as human capital development, economic diversification, road infrastructure improvements, and increased energy self-sufficiency (based on alternative energies that can displace diesel dependence). 
Table 1. Assessing the different modes of distribution and investment

\begin{tabular}{|c|c|c|c|c|}
\hline & $\begin{array}{l}\text { Individual } \\
\text { payment }\end{array}$ & $\begin{array}{l}\text { Programs and } \\
\text { services }\end{array}$ & Infrastructure & Trust funds \\
\hline \multirow[t]{3}{*}{ Advantages } & Individual choices & \multirow{3}{*}{$\begin{array}{l}\text { Local control } \\
\text { over programs } \\
\text { and services }\end{array}$} & \multirow{3}{*}{$\begin{array}{l}\text { Addresses } \\
\text { collective } \\
\text { needs }\end{array}$} & \multirow{3}{*}{$\begin{array}{l}\text { Inter- } \\
\text { generational } \\
\text { equity }\end{array}$} \\
\hline & $\begin{array}{l}\text { Some aspects of } \\
\text { intra-generational } \\
\text { equity }\end{array}$ & & & \\
\hline & $\begin{array}{l}\text { Contributes to } \\
\text { income and food } \\
\text { security }\end{array}$ & & & \\
\hline \multirow[t]{4}{*}{ Disadvantages } & Negative effects & \multirow{4}{*}{$\begin{array}{l}\text { Other levels of } \\
\text { government } \\
\text { tend to lower } \\
\text { their transfer }\end{array}$} & \multirow{4}{*}{$\begin{array}{l}\text { High cost } \\
\text { Maintenance } \\
\text { cost can be } \\
\text { prohibitive }\end{array}$} & \multirow{4}{*}{$\begin{array}{l}\text { Doesn't deal } \\
\text { with urgent } \\
\text { needs }\end{array}$} \\
\hline & $\begin{array}{l}\text { (disincentive to } \\
\text { work, substance } \\
\text { abuse) }\end{array}$ & & & \\
\hline & $\begin{array}{l}\text { Lack of } \\
\text { interregional } \\
\text { equity }\end{array}$ & & & \\
\hline & $\begin{array}{l}\text { Lack of long-term } \\
\text { improvement }\end{array}$ & & & \\
\hline Sustainability & Low & Low & Low to High & High \\
\hline
\end{tabular}

The success of revenue allocation appears to be associated with collective investments (short-term or long-term) characterized by a transparent and diversified investment strategy. Most importantly, strong and transparent institutions are key to maximizing the use of resource revenue and mitigating negative impacts. However, the key element, as shown in different research, is the presence of a vision of community development that allows for choosing the best strategies (Cornell and Kalt 2007; Rodon and Schott 2013; O’Faircheallaigh 2016b).

\section{Revenue Allocation Strategies of Canadian IBA Signatories}

Data on modes of allocating resource revenues and profit shares was collected through phone surveys targeting Indigenous communities in Canada that had signed a profit-sharing agreement. This component aimed to provide a community perspective on the various models used to distribute revenues from resource development, and the positive and negative impacts of each method. To do so, we developed an online questionnaire that addressed four main themes: the modes of distribution or investment chosen, the decision-making process, the administration and management of the funds, and the positive and negative impacts of the allocation mode. 
In 2017, there were over 400 active agreements in Canada between a mining company and an Indigenous community, including memorandums of understanding, surface lease agreements, participation agreements, socio-economic agreements, and impact and benefits agreements (Natural Resources Canada, 2017). In 2015, at the time the survey was conducted, forty-two Indigenous communities and/or regional organizations had an active IBA and all of them were contacted to participate in this study. ${ }^{2}$ IBA coordinators or negotiators were mostly approached to fill out the survey, but other community members with a "position," such as social and health program coordinators, were also contacted in order to get a diverse perspective on the social impacts of revenues. Out of these fortytwo communities, twenty-one representatives agreed to participate in the survey, ${ }^{3}$ but did not necessarily answer all questions.

This mixed success in recruiting and engaging community participants in the project could be explained by the sensitive nature of IBA-related research and the confidential and private nature of these agreements. Although our questions did not address confidential aspects, participants may have felt uncomfortable and unsure as to what they could and could not say. Additionally, the difficulties could relate to the methodology itself, which did not permit face-to-face encounters. This highlights the importance of research relationships, particularly when working with Indigenous communities. Despite these obstacles, the results provide an overview of challenges and outcomes of revenue distribution and investment for Indigenous communities. The respondents had the option to keep their community anonymous. A total of eleven participants chose to identify their community - of these, eight were based in Ontario, one in the Yukon, one in British Colombia, and one in New Brunswick.

\section{Distribution and Investment Modes}

The allocation strategies that were described by community and organization representatives fell under four main categories: Community programs and services, resource funds, infrastructure, and direct payments (figures 1 and 2). The most common mode of distribution or investment was funding community services and projects, which included education and training opportunities, employment and business development initiatives, and cultural and social programming such as elder and youth initiatives and community events. Housing and environmental monitoring programs were also funded. Moreover, one community even used revenue to cover medical care fees that were not covered by the public regime. 


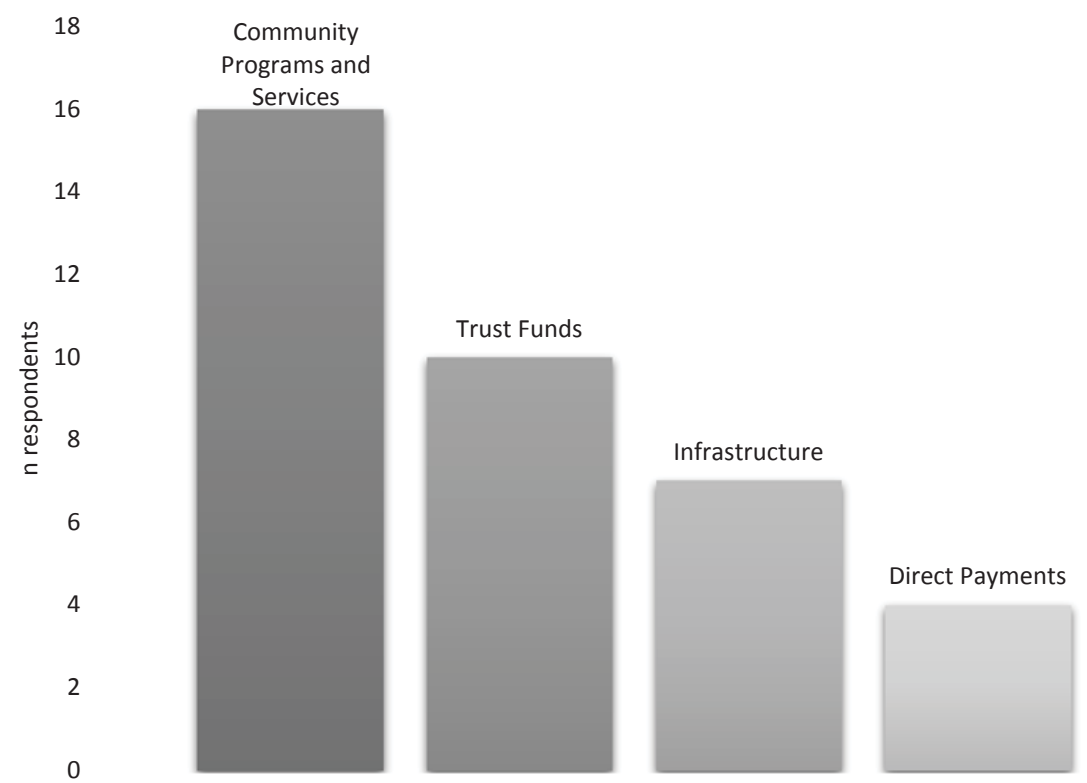

Figure 1. Models of mining revenue allocation adopted by Canadian Indigenous communities

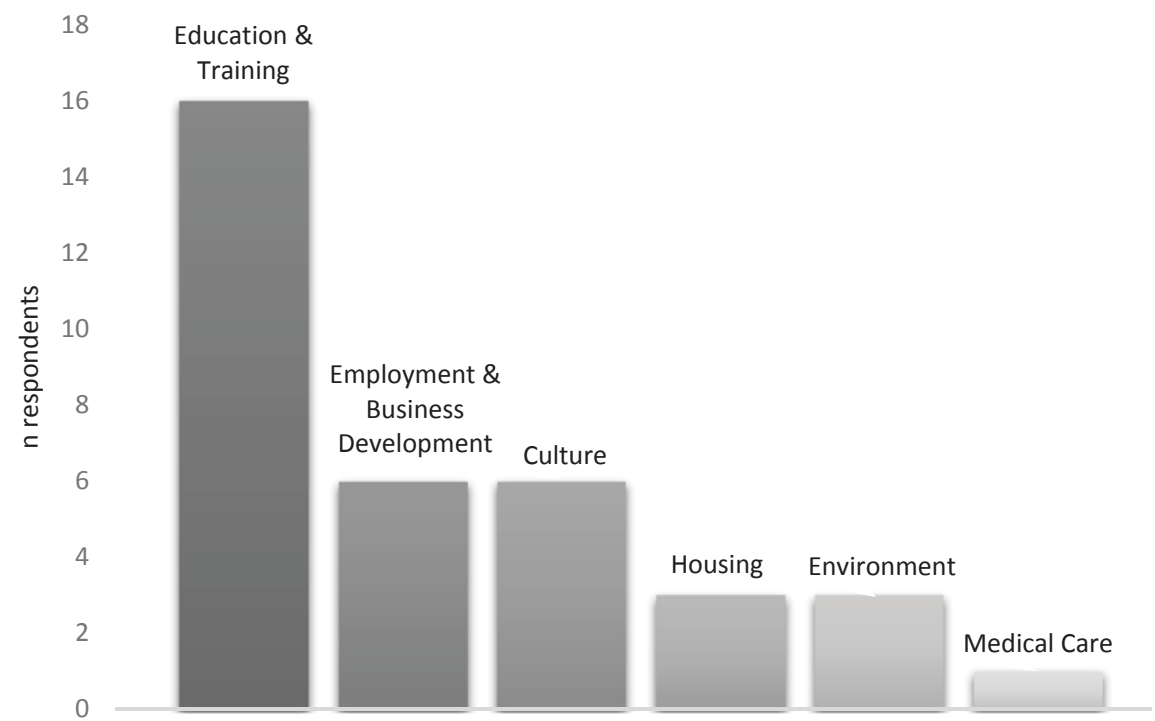

Figure 2. Main categories of community services and projects funded through mining revenues 
Trust funds were the second most common option chosen by respondents, with a large range in operating modes of these funds (administration, spending, and investment types). Revenues were also used for community infrastructure, such as arenas, road maintenance, and the improvement of internet networks. Direct payments to individuals or households was the least common mode of distribution, but were made in a few cases, for instance during the Christmas season.

\section{Decision-Making Process and Funds Management}

During the process of choosing a mode of distribution or investment, most communities and organizations involved legal and financial advisors. The Assembly of First Nations was also involved in one case and facilitated information sharing between communities. Standard practice was then to consult community members and local organizations on which distribution mode to choose and what services and projects to prioritize. Specific groups such as hunters, trappers, and gatherers associations and Elder committees were targeted for the consultation process, in order to bring forward their respective concerns, needs, and expectations. However, one informant mentioned that women's associations and youth organizations were not consulted in the decision process regarding the distribution mode and the projects that would be prioritized. Nevertheless, it was expected that revenue distribution would positively impact all social groups in the community.

The fund management and distribution were predominantly done through the local government (Figure 3), which in most cases was the band council executive. A minority used a third party such as a trustee board, a corporation, or an association. The Assembly of First Nations also acted as fund manager in one case.

\section{Economic and Social Impacts of the Allocation Modes}

When asked about the positive impacts of revenue distribution or investment on community economic development, respondents predominantly mentioned employment (Figure 4). Thus, in addition to direct employment, mining activities can support the parallel contracting of local companies such as catering, housekeeping, and security services. Moreover, the use of revenue for community projects, services, and infrastructure can also lead to the creation of local jobs, which, considering the lack of work opportunities in these often remote locations, presents the potential to galvanize the local economy. However, an informant pointed out that qualified jobs (e.g., mechanics) are mostly awarded to people from outside the community. 


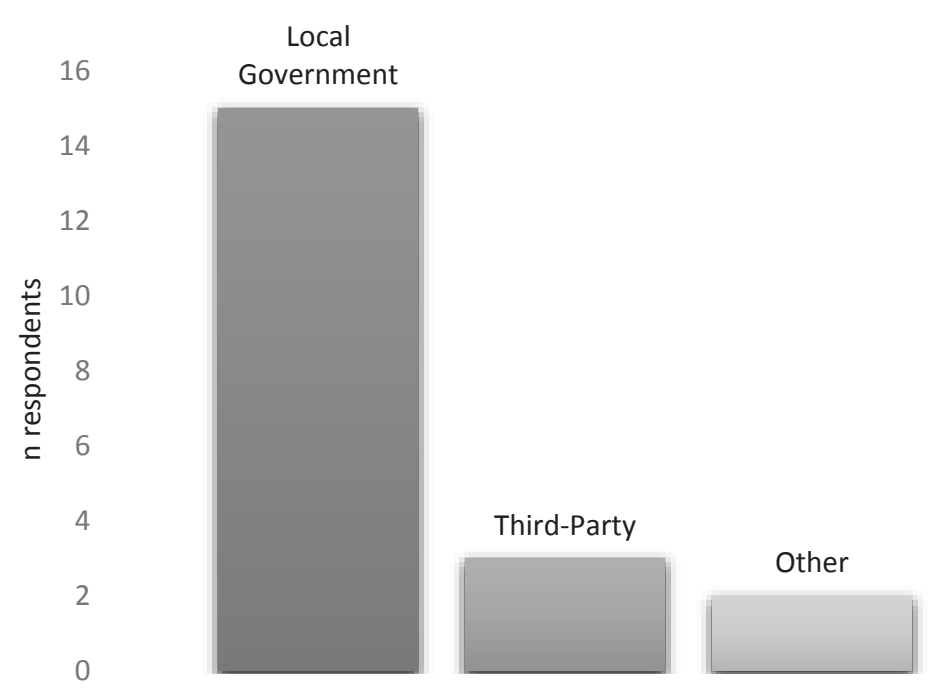

Figure 3. Resource revenues management

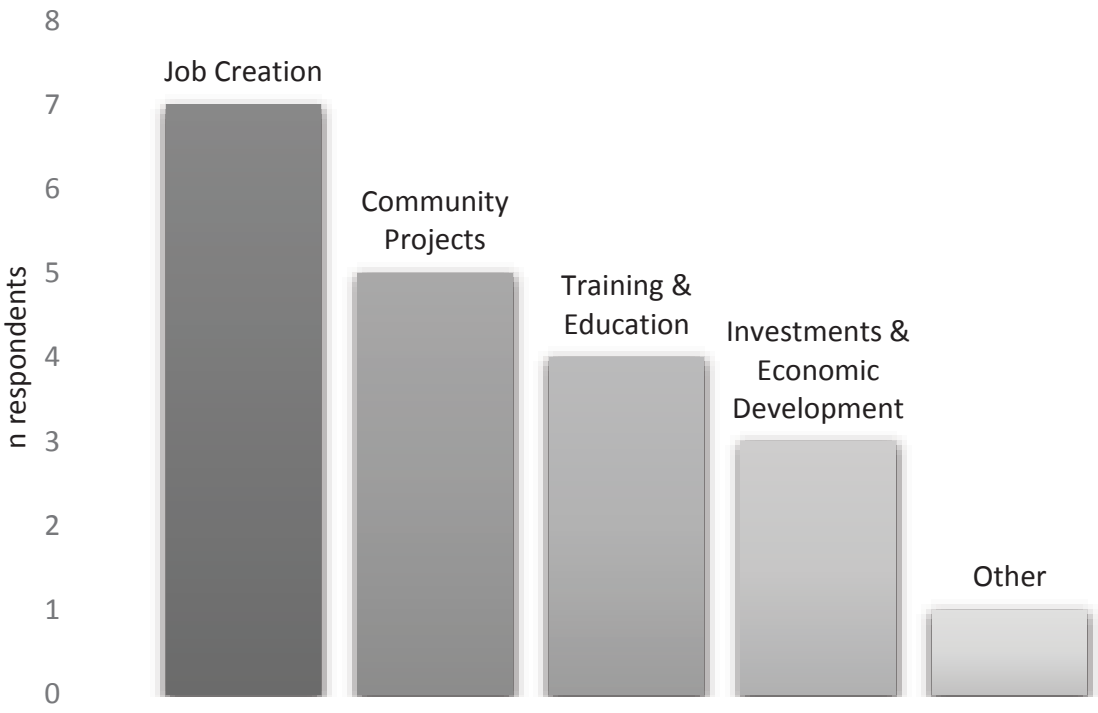

Figure 4. Positive impacts of revenue allocation on economic development 
The importance of mining revenues as additional funding for community projects and opportunities for education and training development was also stressed. As specified by a respondent, "The funds used to improve programs, and in particular the post-secondary program, had a significant impact. Each community was able to fund ten to twenty more students for school." More education and training opportunities could ultimately result in an increase of the local qualified workforce.

One community representative also mentioned the investments in a hydro plant as a major economic impact of resource revenue, as this alternative energy source will allow for reducing the energy costs for community members and could facilitate creating new businesses, thus contributing to long-term sustainability through transforming a nonrenewable asset into a renewable asset.

A recurring concern of several respondents referred to the lack of awareness, transparency, and accountability in the distribution process, sometimes causing distrust and a sense of inequality. Thus, about a third of respondents thought that community members did not all benefit equally from revenue, and half of all respondents said that not all communities in a region benefit in the same way from resource development, clearly an issue of intragenerational equity. Indeed, the revenue sharing formula between affected communities is often based on the level of impacts measured by the proximity to the mine and not on the community needs. Another concern referred to off-reserve members who did not benefit from revenue distribution except in the case of direct payments to individuals that are distributed to all members of the community whether they live in the community or not. A respondent also commented that revenue distribution failed to address urgent needs, and that more direct payments were, therefore, needed.

Direct payments were also criticized, however, by a respondent who mentioned that they had little to no economic impact on the community. This was echoed by another respondent who explained the difficulty in retaining the money from payments locally, as it was spent on goods fabricated elsewhere. One respondent criticized the trust fund strategy, stating that the investments were not productive and that administrative costs were too high. Moreover, the money was not available to address community priorities and urgent needs.

Respondents were less vocal about the impacts of revenue distribution on social community development. Positive impacts were mainly articulated around social and health programming that was said to have improved and which therefore had improved overall community 
well-being. Education and training opportunities were also said to have opened up new possibilities for community members. Spurious effects of mining revenues were mentioned-mostly the rise in alcohol and drug consumption, which would sometimes occur due to direct payments to individuals.

\section{Discussion of Survey Results}

The data collected amongst respondents show that resource revenue use and distribution is a complex endeavour without a clear direction. It seems evident that Indigenous households that are affected by mining projects are in need of both short-term direct transfers (to reduce intragenerational equity) and long-term investment into replacement assets for depleted non-renewable resources (to address intergenerational equity). In addition, almost all of the Indigenous communities need to provide more public infrastructure and services. Using resource revenue for the latter speeds up the process of acquiring important public goods such as arenas and swimming pools, but also introduces additional maintenance and service costs that can use up some of the future revenues. Without a solid tax base (from property and income taxation) communities run the risk of dependence on the boom-and-bust cycles of the mining industry. Furthermore, many of the infrastructure and public goods should be provided by other levels of government. In the short- and medium-term, communities need to provide training and education for residents and entrepreneurs to fully benefit from higher-level jobs and business opportunities. This should be the joint responsibility of central governments, communities, and extractive industries.

The governance, management, and administration of resource revenues is another major challenge. For example, in the vast majority of the communities surveyed, the resource revenues are managed directly by the political authority, in most cases the band council. This goes against the practice of trust funds managed by an arm's-length body that is immune to political influence and political cycles. An arms-length body would insulate fund management from the political short-term needs and would thus tend to foster intergenerational equity more. However, it is reassuring that the majority of resource revenues are invested into community programs and services and trust funds, and only a few communities are using direct payment. On the other hand, this could also be evidence that central governments are failing to provide much-needed services, public goods, and infrastructure in due time. 


\section{Conclusion}

Many Indigenous communities face both urgent immediate needs and long-term development needs. As we have seen, some communities use a mix of distribution and investment strategies, which allows them to address urgent needs such as poverty relief, housing, and food security, and also enables them to keep some funds for medium- and long-term needs. However, communities need to determine what proportion is invested in trust funds, what proportion should be directly distributed (if any), and what proportion should be used for education, training, business development, public goods, and infrastructure. This is clearly a political process, and in order to make this choice communities need to develop a vision that will allow them to weight preferences and start a public debate. However, as long as many Canadian Indigenous communities, especially those in the North, are faced with poverty, difficult social circumstances, and poor access to public services with, for example, issues of overcrowding and lack of clean drinking water, it will be difficult to develop a vision when there are so many urgent needs to address.

We have also seen that in most surveyed communities the trust funds are directly managed by the political authority, thus providing no insulation from political influence. It is, however, difficult, especially for small communities, to set up independent boards to manage trust funds. A solution would be to constitute intercommunity trust funds or trust funds managed by independent authorities, with a board of directors that consists of representatives from the community and other responsible authorities, for the management and investment of resource revenues.

The survey also shows that some Indigenous communities are investing in infrastructure, and environmental and social programs including medical care and social housing. All these programs should normally be funded by the federal and provincial/territorial governments, and this attests to the chronic lack of investment in Indigenous communities in Canada. The mining companies could also contribute more to community infrastructure and its maintenance, and should cover all environmental costs related to the mining operations.

Finally, whatever the choice of distribution or investment mode, in order to ensure sustainable development, communities need to ensure that the lost natural capital (both non-renewable resource depletion and the environmental damage created by the operations) will be replaced for future generations. This can be done in the form of long-term financial investments, investment in renewable resources (e.g., energy, food 
security), human capital, or in long-term physical assets that will contribute to community development. But here again, this lofty ideal will be easier to attain once the basic needs of Canadian Indigenous communities are met.

\section{Acknowledgements}

The authors wish to acknowledge the contribution of Juliette Bastide, Remy Darit Chhem, and Ève Harbour-Marsan who provided expert research assistance for this project. We also want to thank the members of Indigenous communities who agreed to share their experiences about impact and benefit agreements. Finally, we want to acknowledge the two anonymous reviewers who offered both critical and constructive advice, contributing greatly to improve this paper. Note, however, that the content as well as any factual errors are the sole responsibility of the authors. This research was funded by the Resources and Sustainable Development in the Arctic network (ReSDA) and by SSHRC (grant number 890-2012-0111).

\section{Authors}

Thierry Rodon is professor at the Department of Political Science, Université Laval, and holds the research chair of northern sustainable development.

Isabel Lemus-Lauzon is consultation project officer at IDDPNQ, l'Institut de développement durable des Premières Nations du Québec et du Labrador (Institute for Sustainable Development of First Nations of Quebec and Labrador)

Stephan Schott is associate professor at the School of Public Policy, Carleton University.

\section{Notes}

1. The rent is the difference between the market price for an additional unit of the resource and the cost of extracting it.

2. In 2017 the number of active Impact Benefit Agreements in Canada rose to fifty.

3. In two cases, two representatives from the same community or regional organization completed the survey, meaning that eighteen communities/ organizations are represented in total. 


\section{References}

Altman, Jon C., and R. Levitus. 1999. The Allocation and Management of Royalties Under the Aboriginal Land Rights (Northern Territory) Act: Options for Reform. 191. Canberra, Australia: Centre for Aboriginal Economic Policy Research.

Arnold, C., T. Conway, and M. Greenslade. 2011. Cash Transfers Evidence Paper. London, UK: Department for International Development [DFID].

Baena, C., B. Sévi, and A. Warrack. 2012. "Funds from Non-Renewable Energy Resources: Policy Lessons from Alaska and Alberta." Energy Policy 51: 569-677.

Bradshaw, B., and C. McElroy. 2014. "Company Community Agreements in the Mining Sector." Critical Studies on Corporate Responsibility, Governance and Sustainability. Vol. 7. Bingley, UK: Emerald Group Publishing Limited. https://doi.org/10.1108/S2043-905920140000007007.

Birdsall, N., and A. Subramanian. 2004. "Saving Iraq From Its Oil." Foreign Affairs 83 (4): 31-65.

Bunting, D., and W.T. Trulove. 1970. "Some Experiences with Guaranteed Incomes and Lump Sum Payments: The Case of the Klamath Indians." 137th meeting of The American Association for the Advancement of Science, Chicago, December 26, 1970.

Collier, P., R. Van der Ploeg, M. Spence, and A.J. Venables. 2010. "Managing Resource Revenues in Developing Economies." IMF Staff Papers 57 (1): 84-118.

Cornell, S. 2006. "What Makes First Nations Enterprises Successful? Lessons from the Harvard Project." Joint Occasional Papers on Native Affairs. Cambridge: Harvard Project on American Indian Economic Development.

Cornell, S., and J.P. Kalt. 2007. "Two Approaches to the Development of Native Nations: One Works, the Other Doesn't." In Rebuilding Native Nations: Strategies for Governance and Development, edited by Miriam Jorgensen, 3-32. Tucson: University of Arizona Press.

Cornell, S., M. Jorgensen, S. Carroll Rainie, I. Record, R. Seelau, and R. R. Starks. 2007. "Per Capita Distributions of American Indian Tribal Revenues: A Preliminary Discussion of Policy Considerations." Joint Occasional Papers on Native Affairs (JOPNA). Tucson and Cambridge: Udall Center for Studies in Public Policy and Harvard Project on American Indian Economic Development.

Devarajan, S., H. Ehrhart, T.M. Le, and G. Raballand. 2011. Direct Redistribution, Taxation, and Accountability in Oil-Rich Economies: A Proposal. Center for Global Development, Working Paper.

Fischer, Carolyn. 2007. International Experience with Benefit-Sharing Instruments for Extractive Resources. Washington: Resources for the Future.

Gibson, G., and C. O'Faircheallaigh. 2010. IBA Community Toolkit: Negotiation and Implementation of Impact and Benefit Agreements. Ottawa: Walter and Duncan Gordon Foundation. 
Gibson, R. B. 2006. "Sustainability Assessment: Basic Components of a Practical Approach." Impact Assessment and Project Appraisal 24 (3): 1-13.

Gilies, A. 2010. "Giving Money Away? The Politics of Direct Distribution in Resource-Rich States." Center for Global Development, Working Paper 231.

Godden, L. 2009. "Towards a New Ethic in Australian Water Law and Policy." Climate Change on for Young \& Old, edited by J. Sykes, 46-60.

Gosseries, A. 2008. "Theories of Intergenerational Justice: A Synopsis." Surveys and Perspectives Integrating Environment and Society (1.1).

Gupta, S., A. Segura-Ubiergo, and E. Flores. 2014. Direct Distribution of Resource Revenues: Worth Considering? (IMF Staff Discussion Note SDN/14/05). Washington, DC: International Monetary Fund.

Hartwick, J.M. 1977. "Intergenerational Equity and the Investing of Rents from Exhaustible Resources." American Economic Review 67: 972-974.

Hartwick, J.M. 1978. "Substitution Among Exhaustible Resources and Intergenerational Equity." Review of Economic Studies 45: 347-354.

Hill, J.R., and P. A. Groothuis. 2012. “The Effects of Per Capita Tribal Payments on the Fertility, Education, and Labor Force Participation of Tribal Members." Business and Economic Research 2 (2): 106-118.

IBA Research Network. 2012. List of Known IBAs. University of Guelph. http:// www.impactandbenefit.com/IBA_Database_List/.

Mahon, J. 2005. "Liberal States and Fiscal Contracts: Aspects of the Political Economy of Public Finance." Conference paper of the Annual Meeting of the American Political Science Association, Washington.

Morley, S., and D. Coady. 2003. From Social Assistance to Social Development:Targeted Education Subsidies in Developing Countries. Center for Global Development. Peterson Institute Press: All Books, Peterson Institute for International Economics, number cgd376.

Moss, T. 2011. "Oil to Cash: Fighting the Resource Curse through Cash Transfers." Center for Global Development, Working Paper 237.

Natural Resources Canada. 2017. The Atlas of Canada: Indigenous Mining Agreements. Government of Canada. http://atlas.gc.ca/imaema/en/.

Northern Sustainable Development Research Chair. 2013. Développement minier et communautés inuit et cries: comment rendre le développement minier plus durable dans le Nord? Actes du colloque, 81 ${ }^{\mathrm{e}}$ congrès de l'ACFAS, Université Laval. https:// www.chairedeveloppementnord.ulaval.ca/sites/chairedeveloppementnord. ulaval.ca/files/acfasactes_du_colloque.pdf.

NWT (Northwest Territories Legislative Assembly). 1989. Coping with the Cash: A Financial Review of Four Northern Land Claims Settlements .... Yellowknife.

O’Faircheallaigh, C. 2004. “Denying Citizens Their Rights? Indigenous People, Mining Payments and Service Provision." Australian Journal of Public Policy 63 (2): 42-50. 
O'Faircheallaigh, C. 2010. "Aboriginal Investment Funds in Australia." In The Political Economy of Sovereign Wealth Funds, edited by Xu Yi-chong and Gawdat Bahgat, 157-176. London: Palgrave Macmillan.

O'Faircheallaigh, C. 2012, "Curse or Opportunity? Mineral Revenues, Rent Seeking and Development in Aboriginal Australia." In Community Futures, Legal Architecture: Foundations for Indigenous People in the Global Mining Boom, edited by M. Langton and Judy Longbottom, 45-58. Abingdon and New York: Routledge.

O'Faircheallaigh, C. 2013. "Community Development Agreements in the Mining Industry: An Emerging Global Phenomenon." Community Development 44 (2): 222-238.

O'Faircheallaigh, C. 2016a. “Using Revenues from Indigenous Impact and Benefit Agreements: Developing a Conceptual Framework." Western Regional Science Association Annual Meeting, Kona, Hawai'i, 15-17 February 2016.

O'Faircheallaigh, C. 2016b. Negotiations in the Indigenous World. New-York: Routledge.

Palley, T. I. 2003. "Combating the Natural Resource Curse with Citizen Revenue Distribution Funds: Oil and the Case of Iraq." Foreign Policy in Focus (FPIF), FPIF Special Report. http://www.fpif. org/papers/ordf2003.html.

Papillon, M., and T. Rodon. 2017. "Proponent-Indigenous Agreements and the Implementation of the Right to Free, Prior, and Informed Consent in Canada." Environmental Impact Assessment Review 62 (January): 216-224. https://doi. org/10.1016/j.eiar.2016.06.009.

Poole, G. R., M. Pretes, M., and K. Sinding. 1992. "Managing Greenland's Mineral Revenues. A Trust Fund Approach." Resources Policy 18(3): 1991-2204.

Prno, J., B. Bradshaw, and D. Lapierre. 2010. “Impact and Benefit Agreements: Are They Working." In Canadian Institute of Mining, Metallurgy and Petroleum Annual Conference, Vancouver, British Columbia. http://www.impactandbenefit. com/UserFiles/Servers/Server_625664/File/IBA\%20PDF/CIM\%202010\%20 Paper\%20-\%20Prno,\%20Bradshaw\%20and\%20Lapierre.pdf.

Rodon, T., and S. Schott. 2013. “Towards a Sustainable Future for Nunavik.” Polar Record 50 (03): 260-276. https://doi.org/10.1017/S0032247413000132.

Sala-i-Martin, X., and A. Subramanian. 2003. "Addressing the Natural Resource Curse: An Illustration from Nigeria." NBER Working Paper Series, Working Paper 9804. Cambridge, MA: National Bureau of Economic Research.

Schubert, B., and M. Huijbregts. 2006. "The Malawi Social Cash Transfer Pilot Scheme, Preliminary Lessons Learned." Social Protection Initiatives for Children, Women and Families: An Analysis of Recent Experiences, New York, 30-31 October 2006.

Segal, P. 2011. "Resource Rents, Redistribution, and Halving Global Poverty: The Resource Dividend." World Development 39 (4): 475-489. 
Segal, P. 2012. "How to Spend It: Resource Wealth and the Distribution of Resource Rents." Energy Policy 51: 340-348.

Segal, P. 2012b. Fiscal Policy and Natural Resource Entitlements: Who Benefits from Mexican Oil? Oxford: Oxford Institute for Energy Studies.

Soares, F. V., R. Perez Ribas., and R. Guerreiro Osório. 2007. “Evaluating the Impact of Brazil's Bolsa Família: Cash Transfer Programmes in Comparative Perspective." IPC Evaluation Note. Brasilia: International Poverty Center.

Söderholm, P., and N. Svahn. 2014. "Mining, Regional Development and BenefitSharing." Mining and Sustainable Development. Lulea: Lulea University of Technology.

Standing, G. 2008. "How Cash Transfers Boost Work and Economic Security." DESA Working Paper no 58. New York, NY: United Nations Department of Economic and Social Affairs.

Standing, A. 2014. “Ghana's Extractive Industries.” Resources Policy (40): 74-82.

Tsani, S. 2013. "Natural Resources, Governance and Institutional Quality: The Role of Resource Funds." Resources Policy 38: 181-195.

Weinthal, E., and P. Jones Luong. 2006. "Combating the Resource Curse: An Alternative Solution to Managing Mineral Wealth." Perspectives on Politics 4 (1): 35-53.

Weiss, E. B. 1992. "In Fairness to Future Generations and Sustainable Development." American University International Law Review 8, no. 1: 19-26.

World Bank. 2011. "Sharing Mining Benefits in Developing Countries." Extractive Industries for Development 21. Washington, DC: World Bank. https:// openknowledge.worldbank.org/handle/10986/18290. 